\section{Element losses from fields in conventional and conservation tillage in the Atlantic Coastal Plain, Georgia, United States}

\author{
O. Pisani, D. Liebert, D.D. Bosch, A.W. Coffin, D.M. Endale, T.L. Potter, and T.C. Strickland
}

\begin{abstract}
The elemental composition of soil plays an essential role in crop nutrition, but losses from croplands can negatively impact soil fertility and water quality. We compared the impact of strip tillage (ST) and conventional tillage (CT) on element concentrations and loads in surface runoff and subsurface flow from plots under rotational cotton (Gossypium hirsutum L.) and peanut (Arachis hypogaea L.) production with winter cover cropping. Total element concentrations (calcium $[\mathrm{Ca}]$, iron $[\mathrm{Fe}]$, potassium $[\mathrm{K}]$, magnesium $[\mathrm{Mg}]$, manganese $[\mathrm{Mn}]$, sodium $[\mathrm{Na}]$, phosphorus [P], sulfur [S], silicon [Si], and zinc [Zn]) in surface runoff and subsurface flow samples were measured using Inductively Coupled Plasma with Optical Emission Spectroscopy (ICP-OES). Element loads were estimated by multiplying the element concentrations by the surface runoff and drainage volumes. Significantly greater $(p \leq 0.05)$ surface runoff loads for all elements (with the exception of $\mathrm{K}$ and $\mathrm{Zn}$ ) were observed from the CT compared with the ST treatment plots only in 2006, likely due to the combined effects of hydrology and the timing of gypsum amendments that year. Surface runoff was the primary hydrologic pathway for $\mathrm{Fe}, \mathrm{K}, \mathrm{Mn}, \mathrm{P}, \mathrm{Si}$, and $\mathrm{Zn}$ loss while subsurface flow was the primary hydrologic pathway for $\mathrm{Ca}, \mathrm{Mg}$, and S loss with both tillage treatments. Lower concentrations of $\mathrm{Ca}, \mathrm{Mg}, \mathrm{Na}$, and $\mathrm{S}$ in the subsurface flow with ST compared to CT suggest that this tillage practice, in conjunction with the proper timing of fertilizer and soil amendment applications (e.g., poultry litter and gypsum) can be an effective method for reducing element losses from croplands. This finding highlights the importance of conservation practices in sustaining healthy cropland soils while reducing element losses and associated environmental impacts.
\end{abstract}

Key words: agricultural runoff-Conservation Effects Assessment Project (CEAP) conservation tillage-Long-Term Agroecosystem Research (LTAR) network-nutrient infiltration-water quality

The elemental composition of soils plays an important role in crop nutrition because elements are essential macroand micronutrients (Fageria et al. 2002; He et al. 2005; Nagajyoti et al. 2010). Macronutrients include calcium (Ca), potassium $(\mathrm{K})$, magnesium $(\mathrm{Mg})$, phosphorus $(\mathrm{P})$, and sulfur (S), while selected micronutrients are iron (Fe), manganese (Mn), sodium $(\mathrm{Na})$, silicon ( $\mathrm{Si})$, and zinc $(\mathrm{Zn})$, among others. These nutrients are required by plants in various quantities and are essential for crop growth, development, and yield (Nagajyoti et al. 2010; Rashid and Ryan 2004; Reeves and Baker 2000). They can enter agroecosystems through both natural (weathering of soil parent material) and anthropogenic processes accumulation of elements in soils can result in elevated concentrations in surface runoff and contribute to nonpoint source pollution (Conley et al. 2009; He et al. 2004; Moore et al. 1998; Nagajyoti et al. 2010).

In the southeastern Coastal Plain, agricultural productivity is constrained by sandy, highly weathered soils with low organic matter, fertility, and water holding capacity (Hubbard et al. 1985). These regional soil characteristics require relatively high fertilization for adequate crop production. Nutrient loss from croplands may result in the depletion of soil nutrient pools and soil acidification (Pimentel et al. 1995) and can contribute to the eutrophication of water bodies (Conley et al. 2009). Poultry litter, a mixture of manure and bedding material, is valued as a nutrient-rich fertilizer in the region (Moore et al. 1995) and can be a relatively inexpensive source of $\mathrm{Ca}$, copper $(\mathrm{Cu})$, $\mathrm{Fe}, \mathrm{K}, \mathrm{Mg}$, nitrogen $(\mathrm{N}), \mathrm{P}$, and $\mathrm{S}$ (Tazisong et al. 2005). While the application of poultry litter to agricultural land can enhance soil productivity and quality by improving aggregate formation and stability (Tazisong et al. 2005), its repeated use can lead to the accumulation of $\mathrm{P}$ and other nutrients in soils (Kingery et al. 1994; Schomberg et al. 2009) and nonpoint source losses to aquatic ecosystems (Hart et al. 2004).

Although the surface soils of the southeastern Coastal Plain are highly permeable, deep percolation of leached water is impeded by low-permeability materials such as clay-rich argillic horizons and plinthite at depths of up to $1 \mathrm{~m}$ (Bosch et al. 2012). Clay-enriched argillic horizons can reduce infiltration and induce lateral subsurface flow, which can represent $80 \%$ of the total water loss in these landscapes (Hubbard and Sheridan 1983). Conservation practices, such as the adoption of minimum soil disturbance technologies, planting of winter cover crops, and emphasis on riparian corridors to control sediment and nutrient loads, have been

Oliva Pisani is a research chemist, Dan Liebert is a chemist, David D. Bosch is a research hydraulic engineer, Alisa W. Coffin is a research ecologist, and Dinku $M$. Endale is a research agricultural engineer at the Southeast Watershed Research Laboratory, USDA Agricultural Research Service (ARS) in Tifton, Georgia. Thomas L. Potter is retired, and Timothy C. Strickland is a supervisory soil scientist at the Southeast Watershed Research Laboratory, USDA ARS in Tifton, Georgia. 
shown to improve water quality in agricultural watersheds (Tomer et al. 2014). In the southeastern Coastal Plain, a commonly applied conservation practice is strip tillage (ST), in which the soil is left undisturbed from harvest to planting except for narrow tilled strips (30\% of the row width) (USDA NRCS 2006). Strip tillage has been shown to increase infiltration (Bosch et al. 2005, 2012) and subsurface N loadings (Bosch et al. 2015), increase soil carbon (C) and $\mathrm{N}$ accretion (Strickland et al. 2015), increase soil microbial biomass N (Pisani et al. 2017), and reduce sediment runoff (Endale et al. 2014a) and agrichemical loss (Potter et al. 2014, 2015 ) in the region. However, information is lacking on the effects of conservation practices on element losses from croplands in the southeastern Coastal Plain.

The objective of this study was to evaluate tillage impacts on surface and subsurface flow concentrations and loads of macro- and micronutrients from fields under conventional tillage (CT) and ST management. This research was conducted as part of the USDA's Conservation Effects Assessment (CEAP) and Long-Term Agroecosystem Research (LTAR) projects to better understand the effects of agricultural conservation practices on nutrient and element losses in the southeastern Coastal Plain of the United States. Results from this five-year study will assist in evaluating the impacts of agricultural practices on water quality and understanding how conservation practices can help sustain healthy cropland soils by reducing element losses.

\section{Materials and Methods}

Site Description and Crop Management. This research was conducted at the University of Georgia Gibbs Research Farm in Tift County, Georgia (3126'13" N, 8335'17" W). Details about this site's soil, hydrology, and farming practices have been described elsewhere (Bosch et al. 2005, 2012, 2015; Endale et al. 2014a; Pisani et al. 2017; Potter et al. 2014, 2015). The USDA soil survey (websoilsurvey.sc.egov.usda.gov) identifies two soil series at this site: a Tifton loamy sand (fine-loamy, kaolinitic, thermic Plinthic Kandiudult) and a Carnegie sandy loam (fine, kaolinitic, thermic Plinthic Kandiudult). In 1998, a 1.9 ha parcel was divided into one 0.4 ha and two 0.6 ha treatment blocks. The two 0.6 ha blocks were randomly assigned to either CT or ST management and further divided into three 0.2 ha plots across the prevailing 3\% slope (figure 1). Beginning in 1999, plots 1, 3, and 5 were placed in continuous CT, and plots 2, 4, and 6 in ST (figure 1). All plots were managed identically in a peanut (Arachis hypogea L.)-cotton (Gossypium hirsutum L.) rotation. Peanuts were planted (at a depth of $\sim 5 \mathrm{~cm}$ ) in 2004, 2006, and 2008 (table 1), keeping approximately $5 \mathrm{~cm}$ of spacing between plants and $0.9 \mathrm{~m}$ of spacing between rows at a rate of $\sim 215,278$ seeds $\mathrm{ha}^{-1}$. Cotton was planted in 2005 and 2007 (table 1) keeping approximately $7.6 \mathrm{~cm}$ of spacing between plants at a rate of 121,081 seeds $\mathrm{ha}^{-1}$. In all the fields, the crop residue was left on the soil surface after harvest. A winter rye cover (Secale cereale L.) was planted after crop harvest in both CT and ST in all years except 2004, when a mixture of rye and clover (Trifolium incarnatum L.) was planted. Fertilization and pesticide treatments were identical for all plots and followed recommendations by the University of Georgia Extension Service. All plots received $4.5 \mathrm{Mg} \mathrm{ha}^{-1}$ of poultry litter one month prior to planting in 2005 and 2007 (table 1). Prior to this study, all plots

\section{Figure 1}

Layout of the study site showing the six 0.2 ha experimental plots with three under conventional tillage (CT; plots 1, 3, and 5) and three under strip tillage (ST; plots 2, 4, and 6). The 0.4 ha upslope boundary plot is not shown.

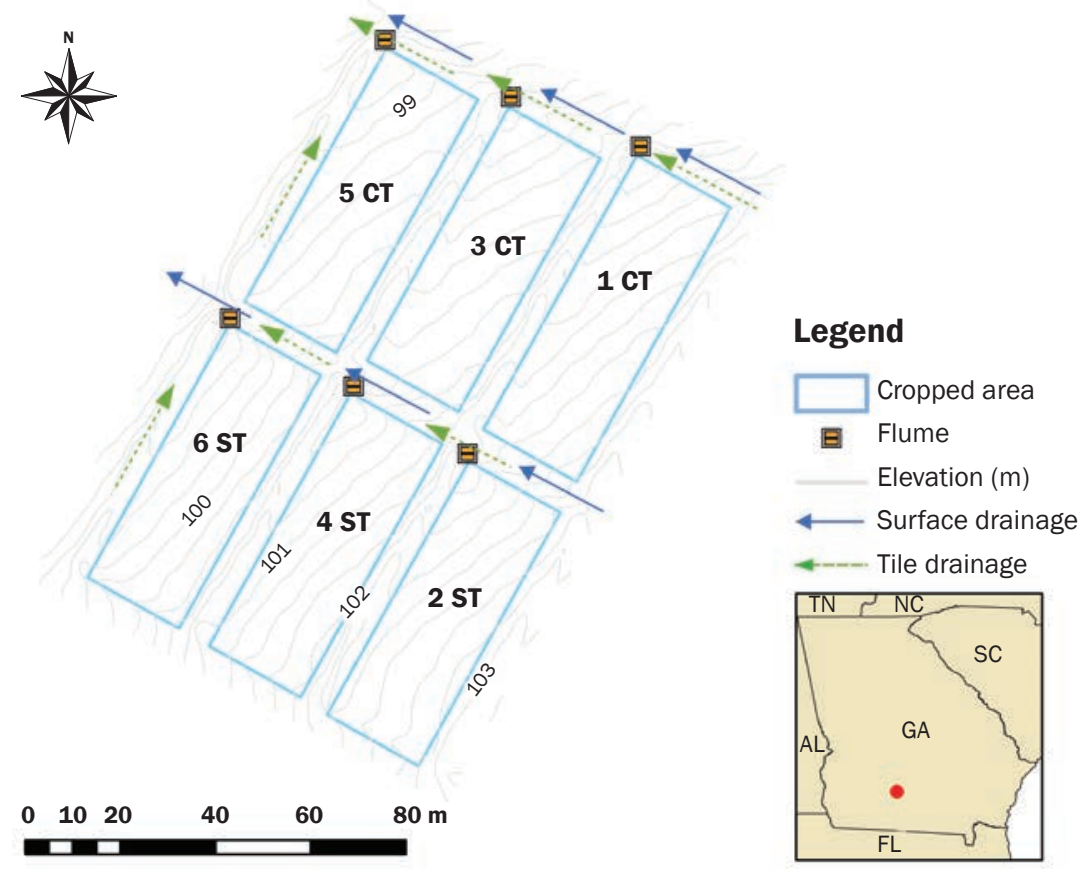

received poultry litter annually from 1999 to 2002. Gypsum $\left(\mathrm{CaSO}_{4}\right)$ was applied $(560 \mathrm{~kg}$ $\mathrm{ha}^{-1}$ ) to all plots in 2004, 2006, and 2008 to address $\mathrm{Ca}$ needs during pegging of peanuts these years (table 1). The cover crops on all plots were terminated with glyphosate about four weeks prior to planting each spring. All cover crop residue was turned into the soil on the CT plots. In 2004, the CT plots were subsequently moldboard plowed to $20 \mathrm{~cm}$ approximately three weeks before planting. In all other years, the CT plots were disk harrowed to $8 \mathrm{~cm}$ and beds formed for planting. In the ST plots, an in-row shank subsoiler was used to create $15 \mathrm{~cm}$ wide strips in the desiccated cover crop mulch for planting with tillage to $20 \mathrm{~cm}$. The ST plots were paratilled in 2004 and 2007. Paratilling, a form of noninversion deep tillage used to loosen the soil in the top 30 to $45 \mathrm{~cm}$, was performed to increase soil porosity and infiltration. Starter and side-dress fertilizer were applied during cotton production years, and no additional fertilizer was applied during peanut years (table 1). Plant water needs were met from rainfall and a solid-set irrigation system. 


\section{Table 1}

Crop rotation, fertilizations, and fertilizer elemental composition including nitrogen (N), phosphorus (P), potassium (K), sulfur (S), and calcium (Ca) content $\left(\mathrm{kg} \mathrm{ha}^{-1}\right)$ applied during the study period.

\begin{tabular}{|c|c|c|c|c|c|c|}
\hline Treatment date & Treatment description & $N\left(k^{\prime} h^{-1}\right)$ & $P\left(k^{\prime} h^{-1}\right)$ & $K\left(\mathrm{~kg} \mathrm{ha}^{-1}\right)$ & $S\left(k_{g ~ h a-1}\right)$ & Ca $\left(k g g ~ h a^{-1}\right)$ \\
\hline May 10, 2004 & Planted peanuts & & & & & \\
\hline July 2, 2004 & Applied gypsum $\left(\mathrm{CaSO}_{4}\right)$ & 0.0 & 0.0 & 0.0 & 131.9 & 164.9 \\
\hline October 5, 2004 & Planted rye and crimson clover & & & & & \\
\hline Year total & & 0.0 & 0.0 & 0.0 & 131.9 & 164.9 \\
\hline March 7, 2005 & Applied lime $\left(\mathrm{CaCO}_{3}\right)$ & 0.0 & 0.0 & 0.0 & 0.0 & 448.8 \\
\hline April 19, 2005 & Applied poultry litter & 121.4 & 37.8 & 91.5 & NM & NM \\
\hline May 23, 2005 & Planted cotton & & & & & \\
\hline May 23, 2005 & Applied starter liquid fertilizer & 17.4 & 0.0 & 0.0 & 3.1 & 0.0 \\
\hline June 22, 2005 & Applied granular fertilizer & 45.3 & 0.0 & 0.0 & 8.1 & 0.0 \\
\hline June 27, 2005 & Applied granular fertilizer & 45.3 & 0.0 & 0.0 & 8.1 & 0.0 \\
\hline November 16, 2005 & Planted rye & & & & & \\
\hline Year total & & 229.4 & 37.8 & 91.5 & 19.3 & 448.8 \\
\hline May 9, 2006 & Planted peanuts & & & & & \\
\hline June 20, 2006 & Applied gypsum $\left(\mathrm{CaSO}_{4}\right)$ & 0.0 & 0.0 & 0.0 & 264.0 & 330.0 \\
\hline October 31, 2006 & Planted rye & & & & & \\
\hline Year total & & 0.0 & 0.0 & 0.0 & 264.0 & 330.0 \\
\hline April 17, 2007 & Applied poultry litter & 139.8 & 57.0 & 101.9 & NM & NM \\
\hline May 1, 2007 & Planted cotton & & & & & \\
\hline May 1, 2007 & Applied starter liquid fertilizer & 17.4 & 0.0 & 0.0 & 3.1 & 0.0 \\
\hline June 7, 2007 & Applied liquid fertilizer & 47.0 & 0.0 & 0.0 & 0.0 & 0.0 \\
\hline October 15, 2007 & Planted rye & & & & & \\
\hline Year total & & 204.2 & 57.0 & 101.9 & 3.1 & 0.0 \\
\hline May 20, 2008 & Planted peanuts & & & & & \\
\hline June 20, 2008 & Applied gypsum $\left(\mathrm{CaSO}_{4}\right)$ & 0.0 & 0.0 & 0.0 & 264.0 & 330.0 \\
\hline October 29, 2008 & Planted rye & & & & & \\
\hline Year total & & 0.0 & 0.0 & 0.0 & 264.0 & 330.0 \\
\hline \multicolumn{2}{|c|}{ Total nutrients from 2004 to 2008} & 433.6 & 94.8 & 193.4 & 682.3 & $1,273.7$ \\
\hline
\end{tabular}

$\mathrm{NM}=$ not measured

Collection and Processing of Surface Runoff and Subsurface Flow Samples. Surface runoff and subsurface flow samples were collected from 2004 to 2008 as described below. Sample collection at this site has previously been described (Bosch et al. 2005, 2012, 2015). Briefly, flow-proportional composite surface runoff samples were collected from each plot $(n=6)$ during each event directly into $9 \mathrm{~L}$ glass jars using ISCO autosamplers (Lincoln, Nebraska). For the subsurface flow samples, tile drains were installed around the two tillage treatment blocks $(n=2)$ to capture lateral subsurface flow, and an H-flume installed at each tile outlet was used for sample collection. From January of 2004 to March of 2006, grab samples were collected twice per week whenever flow was observed. In March of 2006, refrigerated autosamplers were installed at the two tile drain outlets, and flow-proportional samples were collected as for surface runoff.
In the laboratory, unfiltered samples were shaken and split for chemical analyses including pesticides (Potter et al. 2014), dissolved nutrients (Bosch et al. 2015), and total suspended solids (Endale et al. 2014a). An unfiltered subsample was also archived frozen and later analyzed for a suite of elements (aluminum [Al], boron [B], Ca, cadmium [Cd], cobalt [Co], chromium [Cr], $\mathrm{Cu}, \mathrm{Fe}$, $\mathrm{K}, \mathrm{Mg}, \mathrm{Mn}$, molybdenum [Mo], $\mathrm{Na}$, nickel [Ni], P, lead [Pb], S, selenium [Se], Si, titanium [Ti], uranium [U], vanadium [V], and $\mathrm{Zn}$ ) using Inductively Coupled Plasma with Optical Emission Spectroscopy (ICP-OES). Samples ranging in volume from 5 to $40 \mathrm{~mL}$ were thawed and digested using trace metal grade hydrogen chloride $(\mathrm{HCl})$ and nitric acid $\left(\mathrm{HNO}_{3}\right)$ (EPA Method 200.2). The surface runoff samples typically contained visible particulates, and these samples were acidified and allowed to stand for 24 hours prior to digestion. The subsurface flow sam- ples did not contain any visible particulates and were acidified and digested immediately. Following digestion, samples were centrifuged and decanted, diluted (to 15 or $50 \mathrm{~mL}$ ), transferred quantitatively to centrifuge tubes, and analyzed using an iCAP 7400 ICP-OES Duo equipped with a Charge Injection Device detector (ThermoFisher Scientific, San Jose, California). An aliquot of digested sample was aspirated from the centrifuge tube using a CETAC ASX-520 autosampler (Teledyne CETAC Technologies, Omaha, Nebraska) and passed through a concentric tube nebulizer. The resulting aerosol was then swept through the plasma using argon as the carrier gas with a flow rate of $0.5 \mathrm{~L}$ $\min ^{-1}$ and a nebulizer gas flow rate of $0.7 \mathrm{~L}$ $\mathrm{min}^{-1}$. An internal standard (Yttrium in 2\% $\mathrm{HNO}_{3}$ ) was used for instrument calibration and element quantitation. Detection limits, determined as the greater of either the mean plus the Student's $t$-value times the 
standard deviations of concurrently analyzed blank control samples or the lowest nonzero calibration point for a given element (EPA 821-R-16-006), were adjusted using the same correction factors as were applied to account for original and final sample volumes. Samples were analyzed in batches of 48 , including four blanks, three spiked blanks, and one standard reference material for quality control. Additionally, 33 samples were digested in duplicate, and all samples were analyzed on the instrument in triplicate. A target of $10 \%$ error or less was met for the analytes presented here. Data were analyzed using the Thermo iTEVA Control Center (version 2.8.0.97, ThermoFisher Scientific, San Jose, California).

In this study, the most abundant elements were defined as those elements detected in $55 \%$ or more of the entire sample set, including surface runoff and subsurface flow samples $(n=650)$. These elements were $\mathrm{Ca}, \mathrm{Fe}, \mathrm{K}, \mathrm{Mg}$, $\mathrm{Mn}, \mathrm{Na}, \mathrm{P}, \mathrm{S}, \mathrm{Si}$, and $\mathrm{Zn}$ (table 2). Elements detected in less than $55 \%$ of the sample set (table 2) were not evaluated.The total number of samples analyzed varied annually based on the occurrence of flow events (table 3), and the element concentration is summarized for the surface runoff (table 4) and the subsurface flow samples (table 5). Over the course of the five-year observation period, the total number of surface runoff samples analyzed was 152 and 60 for CT and ST practices, respectively. Archived surface runoff samples from the ST plots (2007) and from both the CT and ST plots (2008) were compromised due to a power outage in the storage coolers and were not analyzed (table 4). The total number of subsurface flow samples analyzed was 210 and 228 for CT and ST practices, respectively.

Data Analysis. Surface and subsurface flow measurements were made continuously throughout the study period (Bosch et al. 2012) and were used with concentrations to calculate loads $\left(\mathrm{kg} \mathrm{ha}^{-1}\right)$ for each plot $(n$ $=6)$ and drain tile $(n=2)$. Flows occurred proximate to rain events and were paired with concentrations measured or filled-in as follows: concentrations acquired from flow weighted composite samples were applied to the day they were collected and all of the days up to the day the previous sample was taken. Grab samples were applied to the day they were taken and half of the preceding and subsequent sample periods. When samples were taken but were not available to be analyzed (no archived sample

\section{Table 2}

Elements measured, total number and percentage detected $(n=650)$, mean detected concentration \pm standard deviation, and mean method detection limit $(\mathrm{MDL}) \pm$ standard deviation. Only the elements detected in $55 \%$ of the sample set are discussed in the text (shown in bold font).

\begin{tabular}{|c|c|c|c|c|}
\hline Element & $\begin{array}{l}\# \\
\text { detected }\end{array}$ & $\begin{array}{l}\% \\
\text { detected }\end{array}$ & $\begin{array}{l}\text { Mean concentration } \\
\left(\mathrm{mg} \mathrm{L}^{-1}\right)\end{array}$ & $\begin{array}{l}\text { Mean MDL } \\
\left(\mathrm{mg} \mathrm{L}^{-1}\right)\end{array}$ \\
\hline Aluminum (Al) & 125 & 19 & $7.53 \pm 17.9$ & $0.898 \pm 0.324$ \\
\hline Boron (B) & 240 & 37 & $0.367 \pm 0.114$ & $0.288 \pm 0.104$ \\
\hline Calcium (Ca) & 650 & 100 & $9.11 \pm 5.44$ & $0.194 \pm 0.07$ \\
\hline Cadmium (Cd) & 81 & 12 & $0.00152 \pm 0.00142$ & $0.000634 \pm 0.000229$ \\
\hline Cobalt (Co) & 204 & 31 & $0.00115 \pm 0.000572$ & $0.000895 \pm 0.000323$ \\
\hline Chromium (Cr) & 28 & 4 & $0.0322 \pm 0.0467$ & $0.00766 \pm 0.00276$ \\
\hline Copper $(\mathrm{Cu})$ & 2 & 0 & $0.196 \pm 0.0906$ & $0.0894 \pm 0.0323$ \\
\hline Iron (Fe) & 372 & 57 & $2.39 \pm 10.9$ & $0.0527 \pm 0.019$ \\
\hline Potassium (K) & 650 & 100 & $5.17 \pm 5.11$ & $0.908 \pm 0.328$ \\
\hline Magnesium (Mg) & 650 & 100 & $3.21 \pm 1.7$ & $0.086 \pm 0.031$ \\
\hline Manganese (Mn) & 589 & 91 & $0.0421 \pm 0.0826$ & $0.00448 \pm 0.00162$ \\
\hline Molybdenum (Mo) & 55 & 8 & $0.00198 \pm 0.00211$ & $0.000886 \pm 0.00032$ \\
\hline Sodium (Na) & 648 & 100 & $3.72 \pm 1.61$ & $0.389 \pm 0.14$ \\
\hline Nickel (Ni) & 335 & 52 & $0.00269 \pm 0.00994$ & $0.000895 \pm 0.000323$ \\
\hline Phosphorus (P) & 396 & 61 & $0.254 \pm 0.433$ & $0.00882 \pm 0.00318$ \\
\hline Lead $(\mathrm{Pb})$ & 68 & 10 & $0.0477 \pm 0.0602$ & $0.0187 \pm 0.00674$ \\
\hline Sulfur (S) & 650 & 100 & $4.21 \pm 3.94$ & $0.0884 \pm 0.0319$ \\
\hline Selenium (Se) & 0 & 0 & NA & $0.00901 \pm 0.00325$ \\
\hline Silicon (Si) & 633 & 97 & $2.49 \pm 4.7$ & $0.505 \pm 0.182$ \\
\hline Titanium (Ti) & 168 & 26 & $0.0364 \pm 0.0756$ & $0.00442 \pm 0.00159$ \\
\hline Uranium (U) & 0 & 0 & NA & $0.0892 \pm 0.0322$ \\
\hline Vanadium (V) & 28 & 4 & $0.0649 \pm 0.0811$ & $0.00893 \pm 0.00322$ \\
\hline Zinc (Zn) & 541 & 83 & $0.0502 \pm 0.046$ & $0.0214 \pm 0.00774$ \\
\hline
\end{tabular}

Table 3

Summary of the total annual precipitation, irrigation applied, total water received, and surface and subsurface runoff for the study period.

\begin{tabular}{|c|c|c|c|c|c|c|}
\hline \multirow[b]{2}{*}{ Hydrologic data } & \multicolumn{5}{|l|}{ Year } & \multirow{2}{*}{$\begin{array}{l}\text { Five-year } \\
\text { average }\end{array}$} \\
\hline & 2004 & 2005 & 2006 & 2007 & 2008 & \\
\hline Precipitation (mm) & 1,132 & 1,488 & 1,114 & 910 & 1,361 & 1,201 \\
\hline Irrigation (mm) & 127 & 77 & 146 & 302 & 210 & 172 \\
\hline Total water $(\mathrm{mm})$ & 1,283 & 1,564 & 1,259 & 1,205 & 1,547 & 1,372 \\
\hline CT surface runoff (mm) & 219 & 357 & 155 & 43 & 221 & 199 \\
\hline ST surface runoff (mm) & 164 & 276 & 83 & 6 & 154 & 137 \\
\hline CT subsurface flow (mm) & 162 & 216 & 96 & 63 & 194 & 146 \\
\hline ST subsurface flow (mm) & 187 & 509 & 156 & 78 & 341 & 254 \\
\hline
\end{tabular}

Note: $\mathrm{CT}=$ conventional tillage. $\mathrm{ST}$ = strip tillage. All hydrologic data was taken from Bosch et al. (2012, 2015).

remaining), concentrations were interpolated linearly over time between the preceding and succeeding sample data. If a grab sample followed a flow composite, the flow composite was treated like a grab sample, and the concentration of the flow composite was distributed over half of the intervening sample period. If a flow-weighted composite sample was collected after a grab sample, the concentrations for the intervening days were filled with those from the flow composite, and the grab data were not applied to half of the following sampling period. Surface runoff daily loads were averaged for the three plots of each treatment and summed annually (average annual total load), while the drain tile loads were summed annually (annual total load). Due to the experimental 
Table 4

Annual element concentration averages $\left(\mathrm{mg} \mathrm{L}^{-1}\right)$ for the surface runoff samples. Values are averages \pm standard error. Bold font indicates a significant difference $(p \leq 0.05)$ between conventional (CT) and strip tillage (ST) for a particular year. Values within a treatment row followed by different lowercase letters are significantly different $(p \leq 0.05)$ between years.

\begin{tabular}{|c|c|c|c|c|c|c|}
\hline Element & $\begin{array}{l}\text { Tillage } \\
\text { treatment }\end{array}$ & $2004(n=71)$ & $2005(n=85)$ & $2006(n=34)$ & $2007(n=22)$ & $\begin{array}{l}\text { Three-year } \\
(n=190)^{*}\end{array}$ \\
\hline \multirow[t]{2}{*}{ Calcium (Ca) } & СT & $7.85 \pm 1.35 a$ & $3.92 \pm 0.275 b$ & $4.74 \pm 0.394 a b$ & $3.25 \pm 0.305 b$ & $5.51 \pm 0.575$ \\
\hline & ST & $4.49 \pm 2.61 a$ & $3.32 \pm 0.345 a$ & $4.24 \pm 0.533 a$ & NS & $4.13 \pm 0.846$ \\
\hline \multirow[t]{2}{*}{ Iron (Fe) } & CT & $0.567 \pm 0.177 a$ & $9.70 \pm 2.81 b$ & $6.36 \pm 2.38 a b$ & $3.41 \pm 1.98 \mathrm{ab}$ & $5.20 \pm 1.29$ \\
\hline & ST & $0.572 \pm 0.341 a$ & $0.951 \pm 3.53 a$ & $2.39 \pm 3.22 a$ & NS & $1.14 \pm 1.89$ \\
\hline \multirow[t]{2}{*}{ Potassium (K) } & $\mathrm{CT}$ & $8.40 \pm 1.29 a$ & $6.26 \pm 1.09 a b$ & $3.54 \pm 0.376 b$ & $7.03 \pm 1.44 a b$ & $6.72 \pm 0.744$ \\
\hline & ST & $17.3 \pm 2.49 a$ & $7.37 \pm 1.37 b$ & $3.70 \pm 0.509 b$ & NS & $9.12 \pm 1.09$ \\
\hline \multirow[t]{2}{*}{ Magnesium (Mg) } & CT & $1.74 \pm 0.288 a$ & $1.35 \pm 0.0927 a$ & $1.08 \pm 0.0820 a$ & $0.938 \pm 0.0638 a$ & $1.34 \pm 0.125$ \\
\hline & ST & $1.45 \pm 0.556 a$ & $1.12 \pm 0.116 a$ & $0.844 \pm 0.111 a$ & NS & $1.32 \pm 0.183$ \\
\hline \multirow[t]{2}{*}{ Manganese (Mn) } & CT & $0.0206 \pm 0.00386 a$ & $0.103 \pm 0.0250 b$ & $0.0874 \pm 0.0346 a b$ & $0.0210 \pm 0.00813 a b$ & $0.0650 \pm 0.0125$ \\
\hline & ST & $0.0160 \pm 0.00746 a$ & $0.0277 \pm 0.0314 a$ & $0.0592 \pm 0.0469 a$ & NS & $0.0311 \pm 0.0184$ \\
\hline \multirow[t]{2}{*}{ Sodium (Na) } & CT & $2.78 \pm 0.283 a$ & $3.90 \pm 0.288 b$ & $2.12 \pm 0.198 a$ & $1.65 \pm 0.0946 a$ & $3.12 \pm 0.182$ \\
\hline & ST & $2.82 \pm 0.547 a b$ & $3.96 \pm 0.362 b$ & $1.64 \pm 0.268 a$ & NS & $3.21 \pm 0.267$ \\
\hline \multirow[t]{2}{*}{ Phosphorus (P) } & CT & $0.208 \pm 0.0241 a$ & $0.480 \pm 0.0933 b$ & $0.574 \pm 0.0940 \mathrm{ab}$ & $0.460 \pm 0.0628 b$ & $0.345 \pm 0.0445$ \\
\hline & ST & $0.817 \pm 0.0466 a$ & $0.686 \pm 0.117 a$ & $0.378 \pm 0.127 a$ & NS & $0.697 \pm 0.0656$ \\
\hline \multirow[t]{2}{*}{ Sulfur (S) } & CT & $4.06 \pm 0.883 a$ & $1.15 \pm 0.110 b$ & $1.95 \pm 0.344 a b$ & $1.79 \pm 0.402 a b$ & $2.54 \pm 0.373$ \\
\hline & ST & $1.79 \pm 1.71 a$ & $1.14 \pm 0.139 a$ & $1.58 \pm 0.466 a$ & NS & $0.39 \pm 0.548$ \\
\hline \multirow[t]{2}{*}{ Silicon (Si) } & CT & $1.84 \pm 0.291 a$ & $6.80 \pm 1.49 b$ & $5.25 \pm 1.62 a b$ & $2.90 \pm 1.24 a b$ & $4.40 \pm 0.713$ \\
\hline & ST & $1.12 \pm 0.562 a$ & $1.63 \pm 1.87 a$ & $2.39 \pm 2.20 a$ & NS & $1.66 \pm 1.05$ \\
\hline \multirow[t]{2}{*}{ Zinc $(Z n)$} & CT & $0.0604 \pm 0.00765 a$ & $0.0763 \pm 0.0107 a b$ & $0.0524 \pm 0.0109 a b$ & $0.0306 \pm 0.00358 b$ & $0.0573 \pm 0.00575$ \\
\hline & ST & $0.0993 \pm 0.0148 a$ & $0.0560 \pm 0.0134 a$ & $0.0971 \pm 0.0147 a$ & NS & $0.0862 \pm 0.00847$ \\
\hline
\end{tabular}

Note: NS = no samples for that analyte and treatment.

*Three-year average does not include concentration data for 2007.

design, there was only one subsurface sample per treatment, and treatment comparisons for the subsurface loads were not performed.

Negative element concentration values were replaced with zeros. Values below detection limits were included in the data set and were not substituted by a fraction of the detection limit as this practice can obscure patterns and trends in the data (Helsel 2006). Data distributions were tested for normality with the Shapiro-Wilk test. The data were non-normal, and element concentrations were compared between treatments within years and between years within treatments with a nonparametric survival analysis for interval censored data (SAS PROC ICLIFETEST). An analysis of variance (ANOVA; SAS PROC GLIMMIX) with Tukey-Kramer multiple comparisons adjustment was used to elucidate differences between individual means. The nonparametric and parametric $F$ test results were identical in all but a few cases. Comparisons of surface runoff loads under the two treatments were made with the Wilcoxon Rank Sum test (SAS PROC NPAR1WAY). A principal component analysis (PCA) was performed on the elemental loads (SAS PROC PRINCOMP) by standardizing the loads of each element to a mean of zero and a standard deviation of one and using the resulting correlation matrix.

\section{Results and Discussion}

Annual rainfall and irrigation, surface runoff, and subsurface flow for the study period (2004 to 2008) have been previously described (Bosch et al. 2012, 2015). A brief summary is included here for interpretation of the element concentration and transport data (table 3). The annual total rainfall ranged from a low of $910 \mathrm{~mm}$ in 2007 to a high of $1,488 \mathrm{~mm}$ in 2005 . The irrigation applied averaged $172 \mathrm{~mm} \mathrm{y}^{-1}$ and varied according to the amount of precipitation received during peak growing periods. The annual surface runoff was highest in 2005 and lowest in 2007 (table 3), accounting for 21\% and $3 \%$ of the annual precipitation, respectively. Similarly, the annual lateral subsurface flow was highest in 2005 and lowest in 2007 (table 3 ), accounting for $25 \%$ and $9 \%$ of the annual precipitation, respectively. Over the course of the five-year study period, surface runoff was significantly greater from the CT compared to the ST plots (table 3). The average annual subsurface flow was significantly greater from the ST compared to the CT plots (table 3), due to increased infiltration as a consequence of reduced tillage (Bosch et al. 2012).

Calcium. No significant differences were observed in the surface runoff concentration of $\mathrm{Ca}$ between tillage treatments (table 4). On an annual basis, the concentration of $\mathrm{Ca}$ in surface runoff from the CT plots was highest in 2004 and decreased over the course of the study period. Elevated Ca concentrations in 2004 were likely due to the application of gypsum that year (table 1). However, elevated $\mathrm{Ca}$ concentrations were not observed in 2006 (table 4) despite applying two times the amount of $\mathrm{Ca}$ in 2006 than in 2004 (table 1). The low Ca concentrations observed in 2005 and 2007 may be due to the application of poultry litter in those years (table 1), which has been shown to reduce Ca runoff in Coastal Plain soils (Endale et al. 2014b). The reduction in $\mathrm{Ca}$ concentration in surface runoff may reflect its complexation with $\mathrm{P}$ from the poultry litter via the formation of less soluble calcium 


\section{Table 5}

Annual element concentration averages $\left(\mathrm{mg} \mathrm{L}^{-1}\right)$ for the lateral subsurface flow samples. Values are averages \pm standard error. Bold font indicates a significant difference $(p \leq 0.05)$ between conventional (CT) and strip tillage (ST) for a particular year. Values within a treatment row followed by different lowercase letters are significantly different $(p \leq 0.05)$ between years.

\begin{tabular}{|c|c|c|c|c|c|c|c|}
\hline Element & $\begin{array}{l}\text { Tillage } \\
\text { treatment }\end{array}$ & $2004(n=51)$ & $2005(n=128)$ & $2006(n=108)$ & $2007(n=69)$ & $2008(n=82)$ & Five-year $(n=438)$ \\
\hline \multirow[t]{2}{*}{ Calcium (Ca) } & СT & $11.4 \pm 0.349 a$ & $12.0 \pm 0.335 a$ & $12.8 \pm 0.336 a b$ & $14.0 \pm 0.768 b c$ & $15.3 \pm 0.334 c$ & $13.1 \pm 0.201$ \\
\hline & ST & $8.00 \pm 0.304 a$ & $9.23 \pm 0.320 a b$ & $10.4 \pm 0.312 b$ & $8.93 \pm 0.673 a$ & $9.21 \pm 0.387 a b$ & $9.31 \pm 0.193$ \\
\hline \multirow[t]{2}{*}{ Iron (Fe) } & CT & $0.468 \pm 0.179 a$ & $0.327 \pm 0.0987 a$ & $0.106 \pm 0.0210 \mathrm{~b}$ & $0.155 \pm 0.0589 a$ & $0.176 \pm 0.0531 a$ & $0.231 \pm 0.0380$ \\
\hline & ST & $0.0738 \pm 0.156 a$ & $0.148 \pm 0.0942 a$ & $0.0761 \pm 0.0195 a$ & $0.152 \pm 0.0517 a$ & $0.104 \pm 0.0615 a$ & $0.114 \pm 0.0365$ \\
\hline \multirow[t]{2}{*}{ Potassium (K) } & СT & $3.59 \pm 0.224 a$ & $3.94 \pm 0.165 a$ & $3.90 \pm 0.108 a$ & $3.55 \pm 0.168 a$ & $3.88 \pm 0.237 a$ & $3.82 \pm 0.0825$ \\
\hline & ST & $4.11 \pm 0.195 a$ & $4.80 \pm 0.157 b$ & $4.33 \pm 0.100 \mathrm{ab}$ & $3.93 \pm 0.147 a$ & $3.99 \pm 0.274 a$ & $4.32 \pm 0.0792$ \\
\hline \multirow[t]{2}{*}{ Magnesium (Mg) } & CT & $4.21 \pm 0.109 a$ & $4.45 \pm 0.121 a$ & $4.42 \pm 0.0858 a$ & $4.63 \pm 0.169 \mathrm{ab}$ & $4.95 \pm 0.0847 \mathrm{~b}$ & $4.56 \pm 0.0547$ \\
\hline & ST & $3.29 \pm 0.0947 a$ & $3.80 \pm 0.115 b c$ & $4.01 \pm 0.0796 c$ & $3.48 \pm 0.149 a b$ & $3.82 \pm 0.0982 b c$ & $3.74 \pm 0.0525$ \\
\hline \multirow[t]{2}{*}{ Manganese (Mn) } & CT & $0.0243 \pm 0.00707 a$ & $0.0271 \pm 0.00192 a$ & $0.0243 \pm 0.000883 a$ & $0.0221 \pm 0.00212 \mathrm{ab}$ & $0.0174 \pm 0.000778 \mathrm{~b}$ & $0.0233 \pm 0.00109$ \\
\hline & ST & $0.0563 \pm 0.00616 a$ & $0.0405 \pm 0.00183 b$ & $0.0380 \pm 0.000820 b$ & $0.411 \pm 0.00186 b$ & $0.0361 \pm 0.000913 b$ & $0.0413 \pm 0.00104$ \\
\hline \multirow[t]{2}{*}{ Sodium (Na) } & CT & $4.18 \pm 0.0937 a b$ & $4.01 \pm 0.0833 a$ & $4.56 \pm 0.116 b$ & $5.33 \pm 0.179 c$ & $6.17 \pm 0.111 d$ & $4.83 \pm 0.0694$ \\
\hline & ST & $2.71 \pm 0.0816 a$ & $2.88 \pm 0.0795 a$ & $3.57 \pm 0.108 b$ & $3.53 \pm 0.157 b$ & $4.11 \pm 0.128 c$ & $3.33 \pm 0.0666$ \\
\hline \multirow[t]{2}{*}{ Phosphorus (P) } & CT & $0.0126 \pm 0.00348 a$ & $0.0109 \pm 0.00175 a$ & $0.0116 \pm 0.00136 a$ & $0.0129 \pm 0.00258 a$ & $0.0178 \pm 0.00172 a$ & $0.0131 \pm 0.000896$ \\
\hline & ST & $0.00526 \pm 0.00303 a$ & $0.00876 \pm 0.00167 a b$ & $0.0102 \pm 0.00126 \mathrm{ab}$ & $0.0132 \pm 0.00226 b$ & $0.0102 \pm 0.00200 \mathrm{ab}$ & $0.00967 \pm 0.000860$ \\
\hline \multirow[t]{2}{*}{ Sulfur (S) } & CT & $5.07 \pm 0.249 a$ & $4.65 \pm 0.172 a$ & $5.42 \pm 0.288 a$ & $9.26 \pm 0.530 b$ & $11.9 \pm 0.313 c$ & $7.15 \pm 0.200$ \\
\hline & ST & $3.06 \pm 0.217 a$ & $2.63 \pm 0.164 a$ & $2.93 \pm 0.267 a$ & $4.49 \pm 0.465 b$ & $4.93 \pm 0.363 b$ & $3.43 \pm 0.192$ \\
\hline \multirow[t]{2}{*}{ Silicon (Si) } & CT & $2.38 \pm 0.196 a$ & $2.13 \pm 0.100 a$ & $1.45 \pm 0.0519 b$ & $1.88 \pm 0.158 b$ & $2.48 \pm 0.0813 a$ & $1.95 \pm 0.0535$ \\
\hline & ST & $2.18 \pm 0.170 a b$ & $1.98 \pm 0.0957 b$ & $1.40 \pm 0.0482 c$ & $1.65 \pm 0.138 b$ & $2.26 \pm 0.0942 a$ & $1.92 \pm 0.0514$ \\
\hline \multirow[t]{2}{*}{ Zinc (Zn) } & CT & $0.0183 \pm 0.00162 a$ & $0.0228 \pm 0.00123 a$ & $0.0357 \pm 0.00324 b$ & $0.0403 \pm 0.00506 b$ & $0.0668 \pm 0.00380 c$ & $0.0377 \pm 0.00169$ \\
\hline & ST & $0.0210 \pm 0.00141 a$ & $0.0250 \pm 0.00117 a$ & $0.0359 \pm 0.00301 b$ & $0.0489 \pm 0.00444 c$ & $0.0465 \pm 0.00441 b c$ & $0.0346 \pm 0.00163$ \\
\hline
\end{tabular}

phosphates. In the lateral subsurface flow samples, the concentration of Ca was significantly higher in the CT compared to the ST plots for all years of the study period $(p \leq$ 0.05 ; table 5$)$. Strip tillage can result in larger subsurface flow volumes compared to CT (table 3) (Bosch et al. 2012), and the lower $\mathrm{Ca}$ concentrations observed with this tillage practice may be caused by dilution. On an annual basis, the $\mathrm{Ca}$ concentration in the subsurface flow from the CT plots was highest at the end of the study period when water inputs were lowest (2007 and 2008; table 3). Calcium loads were higher in the subsurface flow compared to surface runoff for all years and regardless of tillage treatment (figure $2 \mathrm{a}$ ). The surface runoff loads were significantly higher with $\mathrm{CT}$ compared to ST practices only in 2006, corresponding to greater runoff volumes with the CT practice (table 3 ) (Bosch et al. 2012). Elevated total (surface and subsurface) Ca loads were observed in 2005 (figure 2a), which was the year of highest $\mathrm{Ca}$ additions (table 1 ) and also the wettest year of the study period (table 3 ). The total Ca loss over the five-year study period was 111 and $122 \mathrm{~kg} \mathrm{ha}^{-1}$ with CT and ST management, respectively. These losses represent $8.7 \%$ and $9.6 \%$ of the $\mathrm{Ca}$ applied in the form of gypsum over the five-year study period $\left(1,273.9 \mathrm{~kg} \mathrm{ha}^{-1}\right.$; table 1) with CT and ST management, respectively.

Iron. No significant differences were observed in the surface runoff and subsurface flow concentrations of Fe between CT and ST treatments (tables 4 and 5). On an annual basis, the concentration of $\mathrm{Fe}$ in the surface runoff was significantly higher in 2005 compared to other years for the CT treatment only (table 4). Poultry litter, which was applied in 2005 (table 1), can contain fairly high concentrations of $\mathrm{Fe}$ (133 to 595 $\mathrm{mg} \mathrm{kg}^{-1}$ soil) (Jackson et al. 2003) and has been shown to increase $\mathrm{Fe}$ concentration in runoff from agricultural fields (Moore et al. 1998). However, elevated Fe concentrations were not observed in 2007 (table 4) when poultry litter was also applied (table 1). In the subsurface flow from the CT plots, lower $\mathrm{Fe}$ concentrations were observed in 2006 compared to other years (table 5), possibly due to the lack of poultry litter and fertilizer applications that year (table 1). Iron loads were greater from surface runoff compared to subsurface flow for all years and treatments (figure 2b). Elevated sediment loads associated with high runoff volumes have been observed with CT (Endale et al. 2014a).
Surface soils at this site can contain up to $31 \mathrm{~kg} \mathrm{ha}^{-1}$ of Fe (unpublished data), which may suggest an association between elevated sediment and Fe runoff loads. Surface runoff $\mathrm{Fe}$ loads were significantly greater with CT compared to ST management in 2005 and 2006 (figure 2b) when elevated runoff volumes were also observed (table 3) (Bosch et al. 2012). Elevated total Fe loads were observed in 2006, regardless of treatment (figure 2b). The total Fe lost throughout the five-year study period was 38 and $9 \mathrm{~kg} \mathrm{ha}^{-1}$ with CT and ST management, respectively. The higher total amount of Fe lost in surface runoff compared to subsurface flow may be linked to greater sediment loads observed with this tillage practice (Endale et al. 2014a) and our use of unfiltered samples for the ICP-OES analyses.

Potassium. The concentration of $\mathrm{K}$ in the surface runoff from the ST plots was significantly higher than the surface runoff from the CT plots only in 2004 (table 4), likely resulting from lower surface volumes with the ST practice (table 3) (Bosch et al. 2012). On an annual basis, the concentration of $\mathrm{K}$ in the surface runoff was lowest in 2006, regardless of tillage treatment. In the subsurface flow, significant treatment differences 


\section{Figure 2}

Annual averages of surface runoff and subsurface flow loads $\left(\mathrm{kg} \mathrm{ha}^{-1}\right)$ of (a) calcium, (b) iron, (c) potassium, (d) magnesium, (e) manganese, (f) sodium, (g) phosphorus, (h) sulfur, (i) silicon, and (j) zinc with conventional (CT) and strip tillage (ST) management. Significant differences ( $p \leq$ $0.05)$ in surface runoff loads between tillage treatments are indicated by an asterisk $\left({ }^{\star}\right)$. (a)

(c)
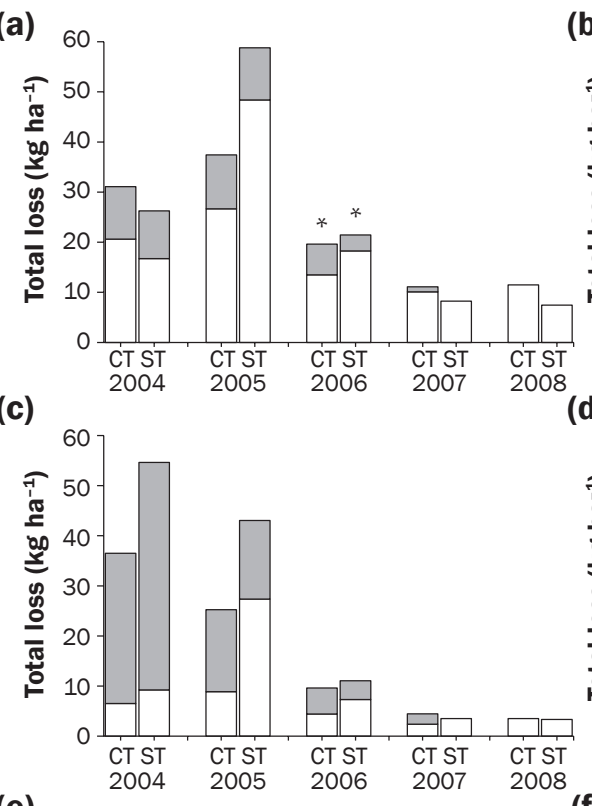

(e)

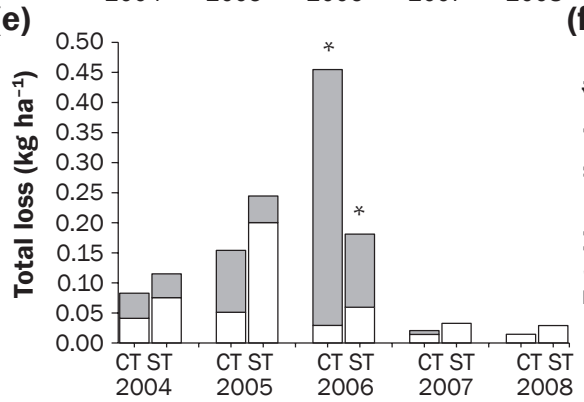

(g)
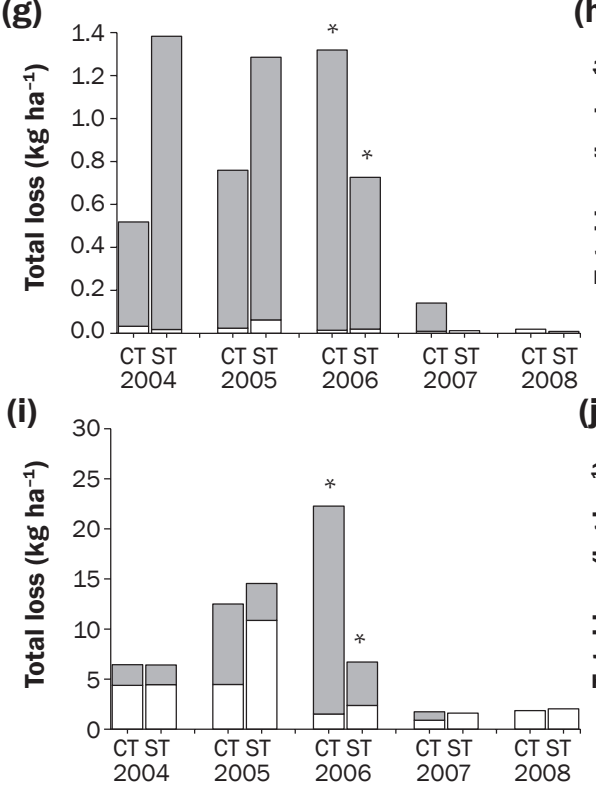

(b)

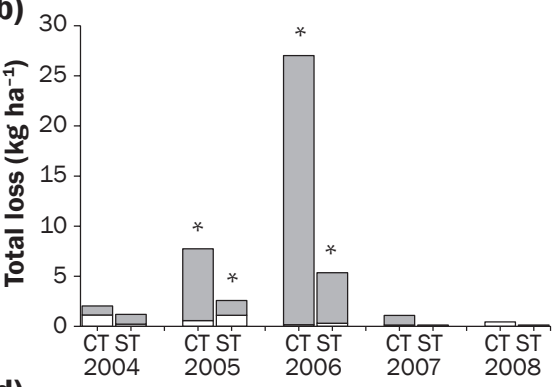

(d)

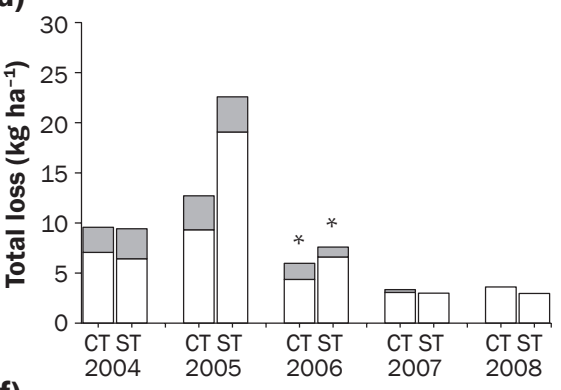

(f)

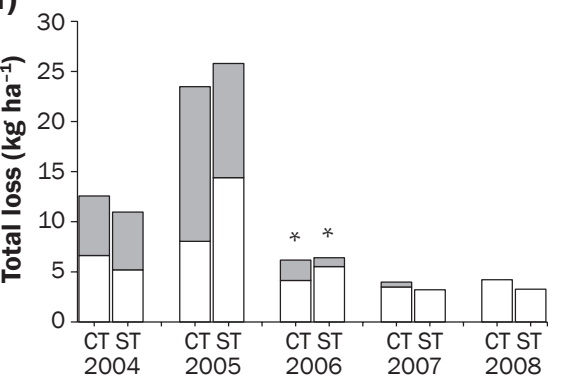

(h)

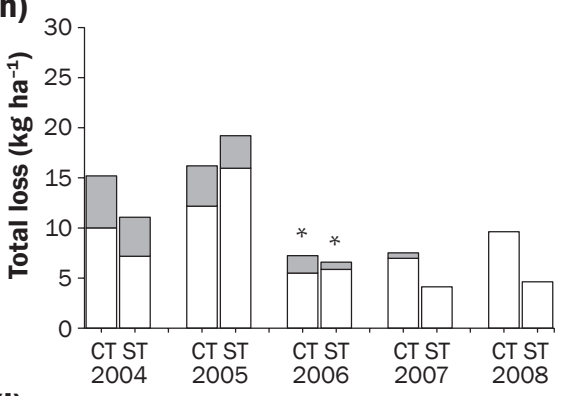

(j) 0.50

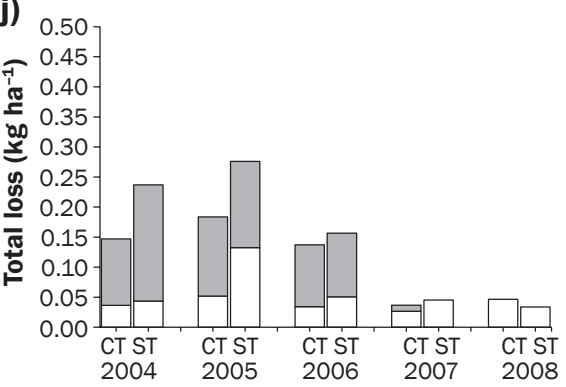

\section{Legend}

$\square$ Surface runoff $\square$ Subsurface flow in the concentration of $\mathrm{K}$ were observed in 2005 and 2006, with higher values from the ST plots in both years (table 5). Elevated K concentrations with ST likely correspond to higher subsurface flow reported with this tillage practice in these two years (Bosch et al. 2012). The concentration of $K$ in the subsurface flow was not different between years with CT but was significantly higher in 2005 compared to other years with ST (table 5). The poultry litter applied in 2005 contained $\mathrm{K}$ (91.5 $\mathrm{kg} \mathrm{ha}^{-1}$; table 1), which may have resulted in elevated $\mathrm{K}$ concentrations in the subsurface flow in that year. However, elevated $\mathrm{K}$ concentrations were not observed in 2007 when $\mathrm{K}$ was also added in poultry litter (101.9 $\mathrm{kg} \mathrm{ha}^{-1}$; table 1). In 2004, elevated K loads occurred in the surface runoff, regardless of tillage treatment (figure 2c). Elevated dissolved $\mathrm{K}$ loads have also been observed in 2004 and 2005 at the Gibbs Research Farm and were attributed to large runoff events in those years (Bosch et al. 2015). The total $\mathrm{K}$ lost over the five-year study period was 79 and $116 \mathrm{~kg} \mathrm{ha}^{-1}$ with CT and ST management, respectively. This $\mathrm{K}$ loss represents $40.8 \%(\mathrm{CT})$ and $60 \%(\mathrm{ST})$ of the total $\mathrm{K}$ applied over the five-year study period (193.4 $\mathrm{kg} \mathrm{ha}^{-1}$; table 1).

Magnesium. No significant differences were observed in the surface runoff concentration of $\mathrm{Mg}$ between $\mathrm{CT}$ and $\mathrm{ST}$ treatments (table 4). Furthermore, the concentration of $\mathrm{Mg}$ in the surface runoff did not change annually, regardless of tillage treatment. In the subsurface flow samples, the concentration of $\mathrm{Mg}$ was higher in the CT compared to the ST plots for all years (table 5). As in the case of $\mathrm{Ca}$, the lower $\mathrm{Mg}$ concentrations observed with ST may be caused by higher subsurface flow volumes with this tillage practice (table 3; Bosch et al. 2012) and subsequent dilution of the $\mathrm{Mg}$ concentration. On an annual basis, elevated $\mathrm{Mg}$ concentrations in the subsurface flow were observed in 2008 with CT and in 2006 with ST management. Gypsum, which can also contain Mg (Endale et al. 2014b), was applied in both 2006 and 2008 (table 1), likely resulting in elevated $\mathrm{Mg}$ concentrations in the subsurface flow in those years. Magnesium loads were always higher in the subsurface flow compared to the surface runoff samples, regardless of treatment and year (figure 2d). In 2006 the Mg load was significantly higher in the surface runoff from the CT compared to the ST plots. Elevated total Mg loads were observed in 2005, associated 
with higher water losses observed in that year (Bosch et al. 2012). Over the course of the five-year study period, the total $\mathrm{Mg}$ lost was 35 and $46 \mathrm{~kg} \mathrm{ha}^{-1}$ with CT and ST management, respectively.

Manganese. The concentration of $\mathrm{Mn}$ in the surface runoff was not affected by tillage treatments (table 4). On an annual basis, elevated $\mathrm{Mn}$ concentrations in the surface runoff were observed in 2005 under CT management only (table 4). High concentrations of Mn may be due to the application of poultry litter that year (table 1). Poultry litter can contain Mn (Jackson et al. 2003; Moore et al. 1995; Sims and Wolf 1994) and has been shown to increase the concentration of this element in runoff from agricultural fields (Endale et al. 2014b; Moore et al. 1998). However, and as in the case of $\mathrm{Fe}$, elevated $\mathrm{Mn}$ concentrations were not observed in 2007 (table 4) when poultry litter was also applied (table 1). The concentration of Mn in the subsurface flow was higher under ST compared to CT for all years of the study period (table 5). Under CT management lower $\mathrm{Mn}$ concentrations were observed in 2008, while for ST, the values decreased in 2005 and remained constant for the remainder of the study period. The observed annual trends in Mn concentration in the subsurface flow did not appear to be related to years of soil amendment applications. Manganese loads in the surface runoff were significantly higher with CT compared to ST only in 2006, when the total loads were also the highest compared to other years (figure 2e). The total Mn lost throughout the five-year study period was 0.73 and $0.60 \mathrm{~kg} \mathrm{ha}^{-1}$ with $\mathrm{CT}$ and ST management, respectively.

Sodium. The concentration of $\mathrm{Na}$ in the surface runoff was not different between tillage treatments (table 4). On an annual basis, elevated $\mathrm{Na}$ concentrations were observed in 2005, regardless of tillage practice (table 4). Once again, elevated $\mathrm{Na}$ concentrations in 2005 may be due to elevated water losses that year. The concentration of $\mathrm{Na}$ in the subsurface flow was significantly higher in the plots managed with CT compared to ST for all years of the study period (table 5). As in the case of $\mathrm{Ca}$ and $\mathrm{Mg}$, lower $\mathrm{Na}$ concentrations with ST may be due to dilution caused by increased water volumes with this tillage practice (table 3) (Bosch et al. 2012). Elevated $\mathrm{Na}$ concentrations in the subsurface flow were observed in 2008, regardless of tillage treatment (table 5). Sodium loads were sig- nificantly higher in the surface runoff from the CT plots compared to the ST plots only in 2006 (figure 2f). The total $\mathrm{Na}$ loads were highest in 2005 compared to other years (figure 2f). Over the course of the five-year study period, the total $\mathrm{Na}$ lost was $50 \mathrm{~kg} \mathrm{ha}^{-1}$ with both tillage treatments.

Phosphorus. The concentration of $\mathrm{P}$ in surface runoff was significantly higher in the ST compared to the CT plots only in 2004 (table 4). This trend may be due to lower surface volumes with ST compared to CT (table 3) (Bosch et al. 2012). On an annual basis, lower P concentrations were observed in the surface runoff from the CT plots in 2004 compared to other years. Elevated P concentrations in 2005 and 2007 (table 4) are likely due to the application of poultry litter (table 1), which has been shown to enhance $\mathrm{P}$ losses through surface runoff (Endale et al. 2014b). Previous to the study period, poultry litter was applied to all the plots annually from 1999 to 2002. The repeated application of poultry litter can cause $\mathrm{P}$ accumulation in agricultural soils (Kingery et al. 1994) and create a potential for enhanced P losses from croplands. Data from the Gibbs Research Farm show increasing $\mathrm{P}$ content in the top $2 \mathrm{~cm}$ of soil with repeated poultry litter applications (unpublished data). However, elevated $\mathrm{P}$ concentrations were not observed at the beginning of the current study, suggesting that this accumulated $\mathrm{P}$ is complexed and fixed in the soil. In the subsurface flow, significantly higher $\mathrm{P}$ concentrations were observed with CT compared to ST management only in 2008 (table 5). On an annual basis, elevated $\mathrm{P}$ concentrations were observed in 2007 and 2008 (table 5). The majority of $\mathrm{P}$ loads occurred in the surface runoff compared to the subsurface flow for all years and treatments (figure 2g), likely due to the association of $\mathrm{P}$ with the greater amount of sediment particles in the surface runoff. Significantly higher P loads were observed in the surface runoff from the CT compared to the ST plots in 2006 (figure 2g). Over the five-year study period, the total $\mathrm{P}$ lost was 2.8 (3.0\% of the total $\mathrm{P}$ applied) and $3.4 \mathrm{~kg} \mathrm{ha}^{-1}$ (3.6\% of the total $\mathrm{P}$ applied) with CT and ST practices, respectively.

Sulfur. Tillage had no significant effect on the concentration of $\mathrm{S}$ in the surface runoff (table 4). On an annual basis, elevated S concentrations were observed in 2004 for the surface runoff from the CT plots only. Gypsum was applied to all the plots in
2004 (table 1), likely resulting in increased $\mathrm{S}$ concentrations. However, elevated S concentrations were not observed in other years of gypsum amendments (2006 and 2008; table 1). The concentration of $\mathrm{S}$ in the subsurface flow was significantly higher with CT compared to ST for all years (table 5). As in the case of $\mathrm{P}$, elevated $\mathrm{S}$ concentrations were observed at the end of the study period (2007 and 2008) regardless of treatment. In fact, gypsum was applied in equal amounts to plots under both tillage treatments. However, the observed annual differences in S concentration for both the surface runoff and subsurface flow samples do not reflect gypsum additions (table 1), suggesting that $\mathrm{S}$ concentrations may be related to hydrology. The majority of the S loads occurred in the subsurface flow, regardless of year and tillage treatment (figure $2 \mathrm{~h}$ ). The S load in the surface runoff was significantly higher with CT compared to ST only in 2006 (figure 2h). The highest total S loads were observed in 2005 regardless of tillage treatment, and the total S lost over the course of the five-year study period was 56 and $46 \mathrm{~kg} \mathrm{ha}^{-1}$ with CT and ST management, respectively. These losses represent $8.2 \%$ and $6.7 \%$ of the total S applied in the form of gypsum and fertilizer over the course of the five-year study period (682.3 $\mathrm{kg} \mathrm{ha}^{-1}$; table 1) from the CT and ST plots, respectively.

Silicon. The concentration of $\mathrm{Si}$ in the surface runoff was significantly higher in the plots managed with CT compared to ST only in 2005 (table 4). The higher Si concentration in the runoff from the CT plots may be due to increased transport of eroded material with this tillage practice (Endale et al.2014a). Elevated Si concentrations were observed with CT in 2005 (table 4) when higher water volumes have been reported (Bosch et al. 2012). In the subsurface flow, the concentration of Si was not different between tillage treatments (table 5). Regardless of treatment, the annual average Si concentration in the subsurface flow was lowest in 2006 compared to other years (table 5). The Si loads were significantly higher in the surface runoff from the CT compared to the ST plots only in 2006 (figure 2i). On an annual basis, elevated total Si loads were observed in 2005 and 2006 for ST and CT, respectively. The total Si lost over the five-year study period was 45 and $31 \mathrm{~kg} \mathrm{ha}^{-1}$ with CT and ST management, respectively. 


\section{Figure 3}

Principal component analysis of the element load data including (a) the score plot and (b) the loading plot. The first principal component ( $\mathrm{PC}_{1}$ ) explains $60.4 \%$ of the variance and separates the element load data based on sample type (surface runoff vs. subsurface flow). The second principal component (PC2) explains $19.5 \%$ of the variance and separates the data based on years with high flow (2004 to 2005$)$ and low flow (2006 to 2008).

(a)

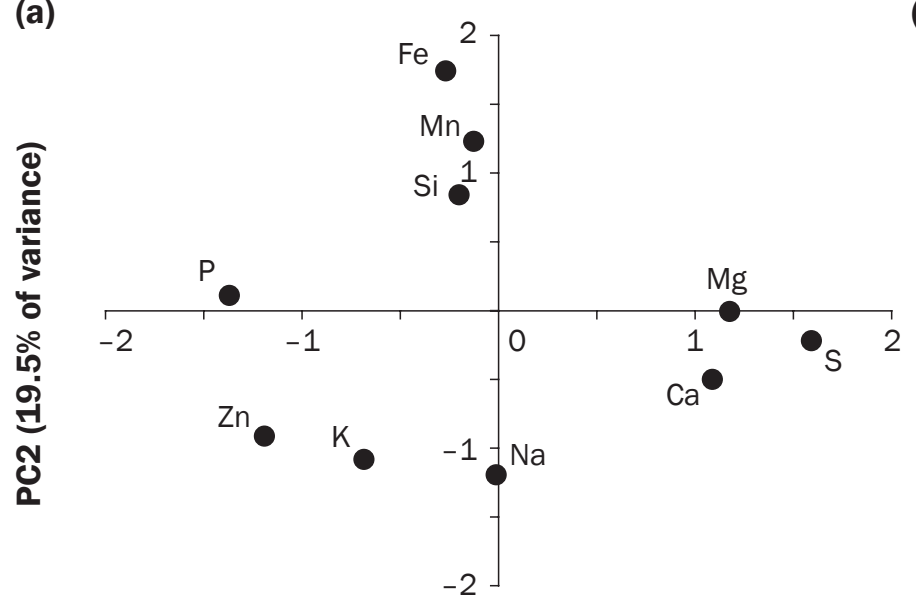

PC1 $(60.4 \%$ of variance)

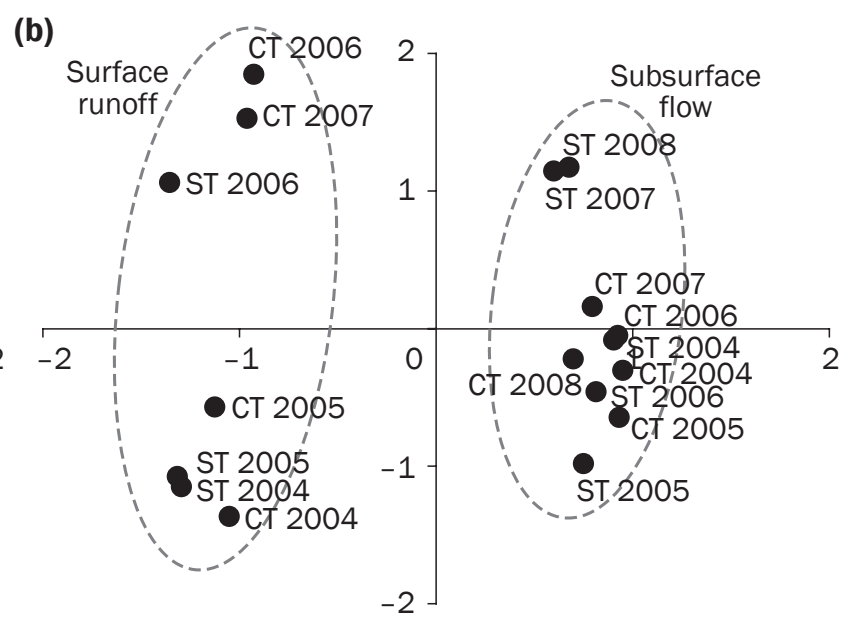

PC1 (60.4\% of variance)
Zinc. The concentration of $\mathrm{Zn}$ in the surface runoff was significantly higher with ST compared to CT management only in 2006 (table 4). On an annual basis, a lower Zn concentration in the surface runoff was observed with CT in 2007 compared to other years (table 4). In the subsurface flow, the concentration of $\mathrm{Zn}$ was higher with CT compared to ST management only in 2008 and was highest for both treatments in that same year (table 5). The annual trends in Zn concentration in the surface runoff and subsurface flow did not appear to be related to year of soil amendment application and may be more dependent on hydrology. Zinc loads were higher in the surface runoff compared to subsurface flow in the first three years of the study, regardless of treatment (figure $2 \mathrm{j}$ ). The five-year Zn loss was 0.55 and $0.75 \mathrm{~kg} \mathrm{ha}^{-1}$ with CT and ST management, respectively.

Patterns of Element Losses via Surface Runoff and Subsurface Flow. To investigate potential patterns in element losses due to tillage treatment (CT versus $\mathrm{ST}$ ) and time (years), a PCA was performed on the element loads (figure 3). The data points representing average element loads were broadly distributed along PC1 (60.4\% of variance) and PC2 (19.5\% of variance; figure $3 \mathrm{a})$. As shown, the PC1 axis represents variations in the sample type with subsurface flow on the positive scale and surface runoff on the negative scale (figure $3 \mathrm{~b}$ ). Calcium, $\mathrm{Mg}$, and $\mathrm{S}$ clustered together on the positive PC1 axis of the PCA (figure 3a) were more strongly correlated to subsurface runoff (positive scale of PC1) and had higher loads in the subsurface flow compared to the surface runoff (figure 2). The relationship between these three elements can be explained as follows. Once applied to the soil, gypsum $\left(\mathrm{CaSO}_{4}\right)$ dissociates with moisture into free $\mathrm{Ca}$ and $\mathrm{SO}_{4}$. The resulting $\mathrm{SO}_{4}$ can bind to excess $\mathrm{Mg}$ in the soil complex forming a soluble compound that can leach out of the crop rooting zone. In addition, $\mathrm{Ca}$ and $\mathrm{Mg}$ behave similarly in soils: both elements have a $2+$ charge, both are in the alkaline earth metal group of elements in the periodic table, and both are found together in many minerals. Thus the PCA results are likely driven by differences in water flow path (i.e., surface runoff versus subsurface flow).

The PC2 axis provided an additional degree of separation regarding year with samples from 2006 to 2008 on the positive scale and samples from 2004 to 2005 on the negative scale (figure $3 \mathrm{~b}$ ). The separation along the PC2 axis was likely due to the varying amount of precipitation and flow observed in the various years. For example, 2004 and 2005 (located on the negative scale of PC2) represent years when high flows for both surface runoff and subsurface flow were observed (table 3) (Bosch et al. 2012). Iron, $\mathrm{Mn}$, and Si clustered together on the positive PC2 axis of the PCA (figure 3a) with greatest losses of these elements observed in surface runoff from 2006 with the CT practice (figure 2). This result is likely due to the high concentration of these elements in the soils at this site (up to 31 and $41 \mathrm{~kg} \mathrm{ha}^{-1}$ of Fe and $\mathrm{Mn}$, respectively; unpublished data) and their association with the reported elevated sediment loads with CT (Endale et al. 2014a). Finally, K, Na, and $\mathrm{Zn}$ clustered together on the negative PC2 axis of the PCA (figure $3 a$ ), and the greatest losses of these elements were generally observed during the years with the greatest total water loss (figure 2). Sodium and $\mathrm{K}$ are usually weakly held on cation exchange sites and their movement out of the soil profile occurs readily depending on precipitation patterns.

The PCA did not indicate variation in element loss due to tillage treatment. The PCA also did not indicate variation in element loss based on years of soil amendments (poultry litter or gypsum). The discrepancy in poultry litter or gypsum influencing the loss of an element in one year and not in another is likely related to the interval between application and runoff/drainage event date. Furthermore, peanut harvest disturbs the soil, and the interval between harvest and runoff/drainage event might have some impact on the observed differences in element loss and water quality. Thus, the weightings of the element loads on the first two principal components suggest that variation in sample type (surface runoff versus subsurface flow; PC1) and amount of water flow (PC2) had 
the largest influence on element losses in agricultural fields of the Coastal Plain. This finding has implications on surface and subsurface elemental transport pathways for model-based projections of precipitation patterns for the Southeast (Ingram et al. 2013).

\section{Summary and Conclusions}

This five-year study compared element losses via surface runoff and subsurface flow from soils of the southeastern Coastal Plain of the United States under CT and ST management. Differences in the annual element concentration in the surface runoff (table 4) and in the subsurface flow (table 5) were largely controlled by differences in runoff volume due to tillage treatments. In particular, greater element concentrations in the subsurface flow with $\mathrm{CT}$ were attributed to lower flow volumes with this tillage practice (Bosch et al. 2012). Significantly greater surface runoff loads for CT compared to ST were observed in 2006 ( $p \leq 0.05$; figure $2)$ and were related to greater surface runoff volume (Bosch et al. 2012) and greater sediment loss (Endale et al. 2014a) from the CT practice. The results from this study indicate that ST can be an effective method for reducing surface runoff related losses of these elements by enhancing infiltration and reducing surface runoff. Furthermore, results indicate that element losses are controlled by the type of runoff (surface versus subsurface) with the majority of Fe, K, Mn, P, Si, and Zn being lost via surface runoff and $\mathrm{Ca}, \mathrm{Mg}$, and $\mathrm{S}$ by subsurface flow (figure 3 ).

Element mobility and losses from croplands are dependent on the total element concentration in the soil, on soil and element properties, and on environmental factors ( $\mathrm{He}$ et al. 2005; Elrashidi et al. 2007). However, not much information exists on the effects of conservation practices on element dynamics in agricultural soils. Conservation practices including leaving crop residues on the soil surface after harvest; planting winter cover crops; and adoption of minimal soil disturbance technologies, such as no till and ST, can improve many soil properties (Lal et al. 2007). Conservation practices can increase the amount of soil organic matter (Dinel et al. 1998; Paustian et al. 2000), which in turn may enhance the soil's ability to absorb $\mathrm{P}$ and other nutrients. In addition, the soil's $\mathrm{pH}$, redox potential, and mineral content can influence the bioavailability and environmental impact of elements (Elrashidi et al. 2007). However, it appears that in the sandy soils of the southeastern Coastal Plain, element transport and loss from croplands mainly follows the local hydrologic patterns (e.g., total amount of precipitation and type of runoff). Future studies should focus on understanding the effects of conservation tillage practices, as well as the timing of poultry litter and gypsum soil amendments, on soil characteristics (e.g., cation exchange capacity, $\mathrm{pH}$, and organic matter content) and their potential relationships to element dynamics in Coastal Plain soils.

\section{Acknowledgements}

This research is a contribution of the USDA Agricultural Research Service (ARS) Gulf Atlantic Coastal Plain LongTerm Agroecosystem Research site. The authors are grateful for the assistance of the following research technicians with the USDA ARS Southeast Watershed Research Laboratory in Tifton, Georgia: Sally Belflower, Chris Clegg, Coby Smith, and Margie Whittle. We gratefully acknowledge statistical and data analysis guidance provided by Deborah Boykin, statistician, USDA ARS, Stoneville, Mississippi (retired). This research and assessment was supported by the USDA Natural Resources Conservation Service Conservation Effects Assessment Project Watershed Assessment Studies and Agricultural Research Service National Program 211.

\section{Disclaimer}

Mention of trade names, commercial products, or companies in this publication does not imply recommendation or endorsement by the USDA Agricultural Research Service.

\section{References}

Bosch, D.D., T.L. Potter, T.C. Strickland, and R.K. Hubbard. 2015. Dissolved nitrogen, chloride, and potassium loss from fields in conventional and conservation tillage. Transactions of the ASABE 58:1559-1571.

Bosch, D.D.,T.L. Potter, C.C.Truman, C.W. Bednarz, and T.C. Strickland. 2005. Surface runoff and lateral subsurface flow as a response to conservation tillage and soil-water conditions. Transactions of the ASAE 48:2137-2144.

Bosch, D.D., C.C. Truman, T.L. Potter, L.T. West, T.C. Strickland, and R.K. Hubbard. 2012. Tillage and slope position impact on field-scale hydrologic processes in the South Atlantic Coastal Plain. Agricultural Water Management 111:40-52

Conley, D.J., H.W. Paerl, R.W. Howarth, D.F. Boesch, S.P. Seitzinger, K.E. Havens, C. Lancelot, and G.E. Likens. 2009. Controlling eutrophication: Nitrogen and phosphorus. Science 323:1014-1015.

DeSutter,T.M., and L.J. Cihacek. 2009. Potential agricultural uses of flue gas desulfurization gypsum in the northern Great Plains. Agronomy Journal 101:817-825.
Dinel, H., C.M. Monreal, and M. Schnitzer. 1998. Extractable lipids and organic matter status in two soil catenas as influenced by tillage. Geoderma 86:279-293.

Elrashidi, M.A., D. Hammer, A. Fares, C.A. Seybold, R. Ferguson, and S.D. Peaslee. 2007. Loss of heavy metals by runoff from agricultural watersheds. Soil Science 172:876-894

Endale, D.M., D.D. Bosch, T.L. Potter, and T.C. Strickland. 2014a. Sediment loss and runoff from cropland in a southeast Atlantic Coastal Plain landscape. Transactions of the ASABE 57:1611-1626.

Endale, D.M., H.H. Schomberg, D.S. Fisher, D.H. Franklin, and M.B. Jenkins. 2014b. Flue gas desulfurization gypsum: Implication for runoff and nutrient losses associated with broiler litter use on pastures on Ultisols. Journal of Environmental Quality 43:281-289.

Fageria, N.K., V.C. Baligar, and R.B. Clark. 2002. Micronutrients in crop production. Advances in Agronomy 77:185-268.

Guo, J.H., X.J. Liu,Y. Zhang, J.L. Shen, W.X. Han, W.F. Zhang, P.K. Christie, W.T. Goulding, P.M. Vitousek, and F.S. Zhang. 2010. Significant acidification in major Chinese croplands. Science 327:1008-1010.

Hart, M.R., B.F. Quin, and M.L. Nguyen. 2004. Phosphorus runoff from agricultural land and direct fertilizer effects: A review. Journal of Environmental Quality 33:1954-1972.

He, Z.L., X.E. Yang, and P.J. Stoffella. 2005. Trace elements in agroecosystems and impacts on the environment. Journal of Trace Elements in Medicine and Biology 19:125-140.

He, Z.L., M.K. Zhang, D.V. Calvert, P.J. Stoffella, X.E. Yang, and S. Yu. 2004. Transport of heavy metals in surface runoff from vegetable and citrus fields. Soil Science Society of America Journal 68:1662-1669.

Helsel, D.R. 2006. Fabricating data: How substituting values for nondetects can ruin results, and what can be done about it. Chemosphere 65:2434-2439.

Hubbard, R.K., C.R. Berdanier, H.F. Perkins, and R.A. Leonard. 1985. Characteristics of selected upland soils of the Georgia Coastal Plain. USDA Agricultural Research Service, ARS-37. Washington DC: USDA Agricultural Research Service.

Hubbard, R.K., and J.M. Sheridan. 1983. Water and nitrate-nitrogen losses from a small upland Coastal Plain watershed. Journal of Environmental Quality 12:291-295.

Ingram, K.T., K. Dow, L. Carter, and J. Anderson. 2013. Climate of the Southeast United States: Variability, Change, Impacts, and Vulnerability. Washington, DC: Island Press.

Jackson, B.P., P.M. Bertsch, M.L. Cabrera, J.J. Camberato, J.C. Seaman, and C.W.Wood. 2003. Trace element speciation in poultry litter. Journal of Environmental Quality 32:535-540.

Kingery,W.L., C.W.Wood,D.P.Delany,J.C.Williams, and G.L. Mullins. 1994. Impact of long-term land application of 
broiler litter on environmentally related soil properties. Journal of Environmental Quality 23:139-147.

Lal, R., D.C. Reicosky, and J.D. Hanson. 2007. Evolution of the plow over 10,000 years and the rationale for no-till farming. Soil and Tillage Research 93:1-12.

Moore, P.A., Jr., T.C. Daniel, J.T. Gilmour, B.R. Shreve, D.R. Edwards, and B.H.Wood. 1998. Decreasing metal runoff from poultry litter with aluminum sulfate. Journal of Environmental Quality 27:92-99.

Moore, P.A., Jr., T.C. Daniel, C.W. Wood, and A.N. Sharpley. 1995. Poultry manure management. Journal of Soil and Water Conservation 50(3):29-35.

Nagajyoti, P.C., K.D. Lee, and T.V.M. Sreekanth. 2010. Heavy metals, occurrence and toxicity for plants: A review. Environmental Chemistry Letters 8:199-216.

Paustian, K., J. Six, E.T. Elliott, and H.W. Hunt. 2000. Management options for reducing $\mathrm{CO}_{2}$ emissions from agricultural soils. Biogeochemistry 48:147-163.

Pimentel, D., C. Harvey, P. Resosudarmo, K. Sinclair, D. Kura, M. McNair, S. Crist, L. Shpritz, L. Fitton, R. Saffouri, and R. Blair. 1995. Environmental and economic costs of soil erosion and conservation benefits. Science 267:1117-1123.

Pisani, O., T.C. Strickland, R.K. Hubbard, D.D. Bosch, A.W. Coffin, D.M. Endale, and T.L. Potter. 2017. Soil nitrogen dynamics and leaching under conservation tillage in the Atlantic Coastal Plain, Georgia, United States. Journal of Soil and Water Conservation 72(5):519-529, doi:10.2489/jswc.72.5.519.

Potter, T.L., D.D. Bosch, and T.C. Strickland. 2014. Comparative assessment of herbicide and fungicide runoff risk: A case study for peanut production in the Southern Atlantic Coastal Plain (USA). Science of the Total Environment 491:1-10.

Potter, T.L., D.D. Bosch, and T.C. Strickland. 2015. Tillage impact on herbicide loss by surface runoff and lateral subsurface flow. Science of the Total Environment 530-531:357-366.

Rashid, A., and J. Ryan. 2004. Micronutrient constraints to crop production in soils with Mediterranean-type characteristics: A review. Journal of Plant Nutrition 27:959-975.

Reeves, R.D., and A.J.M. Baker. 2000. Metal-accumulating plants. In Phytoremediation of Toxic Metals: Using Plants to Clean Up the Environment, ed. I. Raskin and B.D. Ensley, 193-229. New York: Wiley.

Schomberg, H.H., D.M. Endale, M.B. Jenkins, R.R. Sharpe, D.S. Fisher, M.L. Cabrera, and D.V. McCracken. 2009. Soil test nutrient changes induced by poultry litter under conventional tillage and no-tillage. Soil Science Society of America Journal 73:154-163.

Senbayram, M., A. Gransee, V. Wahle, and H. Thiel. 2015. Role of magnesium fertilizers in agriculture: Plant-soil continuum. Crop and Pasture Science 66:1219-1229.

Sims, J.T., and D.C. Wolf. 1994. Poultry manure management: Agricultural and environmental issues. Advanced Agronomy 52:1-83.
Strickland, T.C., B.T. Scully, R.K. Hubbard, D.G. Sullivan, Z. Abdo, M.R. Savabi, R.D. Lee, D.M. Olson, and G.L. Hawkins. 2015. Effect of conservation practices on soil carbon and nitrogen accretion and crop yield in a corn production system in the southeastern Coastal Plain, United States. Journal of Soil and Water Conservation 70(3):170-181, doi:10.2489/jswc.70.3.170.

Tazisong, I.A., Z.N. Senwo, and R.W. Taylor. 2005. Trends in trace elements in an Ultisol impacted by longterm applied broiler litter. Bulletin of Environmental Contamination and Toxicology 75:975-981.

Tomer, M.D., E.J. Sadler, R.E. Lizotte, R.B. Bryant, T.L. Potter, M.T. Moore, T.L. Veith, C. Baffaut, M.A. Locke, and M.R. Walbridge. 2014. A decade of conservation effects assessment research by the USDA Agricultural Research Service: Progress overview and future outlook. Journal of Soil and Water Conservation 69(5):365-373, doi:10.2489/jswc.69.5.365.

USDA NRCS (Natural Resources Conservation Service). 2006. Conservation Practice Standard No. 329: No-till and strip till/direct seed. Washington, DC: USDA Natural Resources Conservation Service.

Zhang, W., C. Yin, C. Chen, A. Chen, X. Xie, X. Fu, H. Hou, and W. Wei. 2016. Estimation of long-term $\mathrm{Ca}^{2+}$ loss through outlet flow from an agricultural watershed and the influencing factors. Environmental Science and Pollution Research doi:10.1007/s11356-016-6145-z. 